Article

\title{
The Nexus between Credit Channels and Farm Household Vulnerability to Poverty: Evidence from Rural China
}

\author{
Hong Sun ${ }^{1,2} \mathbb{D}$, Xiaohong $\mathrm{Li}^{3,4, *}$ and Wenjing $\mathrm{Li}^{1,2}$ \\ 1 School of Economics, Wuhan Textile University, Wuhan 430200, China; hsun@wtu.edu.cn (H.S.); \\ liwjing2007@163.com (W.L.) \\ 2 Center of Industrial Economy, Wuhan Textile University, Wuhan 430200, China \\ 3 School of Economics, Guizhou University, Guiyang 550025, China \\ 4 Insititute of China Karst Rural Revitalization Research, Guizhou University, Guiyang 550025, China \\ * Correspondence: xhli2@gzu.edu.cn
}

Received: 11 February 2020; Accepted: 31 March 2020; Published: 9 April 2020

\begin{abstract}
It is well known that finance is at the core of economic activities, and rural finance is an important force for agricultural development, rural economic growth, and farmer income growth, but how rural credit affects vulnerability to poverty of farm households is not yet known. The study on the nexus between the credit channels and vulnerability to poverty can not only realize targeted poverty alleviation but also promote sustainable rural development. This study measures vulnerability to poverty of Chinese farm households by three-stage feasible generalized least squares (FGLS) and tests for the impact of two credit channels on farm household's vulnerability to poverty based on China Household Finance Survey data. We mainly found that the proportion of structural poverty in western areas is comparatively large, and risky poverty of farm households in eastern areas is relatively serious. The high education cost may be an important factor in farm household poverty; the cost-effectiveness of education is higher than that of earnings. Farm household vulnerability to poverty with folk loans is $0.2 \%$ higher than that of farm households without private credit; however, this is not significant. Farm household vulnerability to poverty with bank credit is $0.4 \%$ lower than households without bank credit, which is significant. For farm households who have a higher level of vulnerability to poverty, the effect of bank credit on reducing vulnerability to poverty is greater. Moreover, we replaced the vulnerability-to-poverty variable with a more rigid indicator to test the relationship between the credit channels and vulnerability to poverty and got the same results as before.
\end{abstract}

Keywords: rural sustainable development; private credit; bank credit; vulnerability to poverty; China Household Finance Survey

\section{Introduction}

Poverty has always been a major problem that the world organizations are committed to solving. It is an important issue concerning people's livelihood and sustainable economic development of the country. China has made great contributions to global poverty reduction (Zhang et al. 2014) [1] and has rich experience in poverty alleviation. Since the 18th National Congress of the Communist Party of China (CPC), general secretary Xi Jinping has led the whole party and the whole nation to a phased victory in poverty alleviation. He has proposed targeted poverty alleviation and attached importance to the quality of poverty alleviation in 2013. The number of poor people has been greatly reduced from 82.49 million in 2013 to 16.6 million in 2018, and the poverty rate also has dropped from 8.5 percent to 1.7 percent (Chen and Ravallion 2013) [2]. However, the target of achieving full poverty alleviation 
under the current standard, and entering an overall well-off society comparatively in 2020 shows that it remains a time-critical and heavy task.

The study of poverty has always been paid much attention by scholars both at home and abroad. From the 1950s, the theme of poverty research was about income poverty. In the 1980s and 1990s, it became ability poverty and the lack of rights. Now, the international community and academia bring poverty thematic research into survival vulnerability and risk-bearing networks of the poor people who encounter future risk shock. In China, the mainstream of poverty measurement methods is to study poverty under current standards (Bourguignon and Chakravarty 2019) [3]. Commonly used indicators include poverty rate, poverty gap, and poverty intensity, and some other indicators, all of which are a kind of static measurement method after the event. Statistically, from 2000 to 2010, two-thirds of the poor have been lifted out of poverty and gone back to poverty. Traditional income or consumption poverty standards ignore those who are not currently poor but may fall into poverty in the future. Vulnerability to poverty can make up for the deficiency of income poverty or consumption poverty standard by predicting the probability of poverty prevalence. It can reflect dynamic information on poverty and be forward-looking (Chaudhuri et al. 2002) [4]. Based on this, formulating anti-poverty policies not only can alleviate poverty, but also prevent poverty before it occurs, so as to improve the effectiveness of anti-poverty policies. Vulnerability to poverty index is an important tool to measure the long-term effectiveness of poverty alleviation mechanism. Studies have shown that more than $80 \%$ of the poor are "sometimes poor" rather than "always poor", mainly due to the fact that such vulnerable groups are vulnerable to various disasters and fall into poverty (World Bank 2001). A family that is not poor now may fall into poverty in the future due to risks, a family that is poor now may be lifted out of poverty or become poorer in the future. Therefore, the application of vulnerability-to -poverty index is comprehensive and accurate (Chaudhuri et al. 2002; Skoufias and Quisumbing, 2005) [5].

Financial instruments are playing an important role in the alleviation impoverishment, which has also been the focus of political and academic circles. Especially since 2003, when the United Nations first proposed the concept of financial inclusion, finance and poverty alleviation have been more closely linked. At the G20 summit in 2010, over 90 countries in the developing world signed the Maya Declaration, which aimed to reduce poverty through financial inclusion. In China, the Third plenary session of the 18th CPC Central Committee in 2013 formally put forward "Development of Inclusive Finance". In January 2016, the State Council of China had issued, "The Plan for Promoting Inclusive Finance Development (2016-2020)", which further clearly emphasized that "small and micro businesses, farmers, low-income urban groups, poor groups, disabled people, elderly and other special groups are the key service objects of inclusive finance in China". The policy meaning of inclusive finance in rural China is to alleviate poverty in rural areas through the full coverage of financial services. Although many studies have concluded the positive effect of financial poverty alleviation from a macro perspective, it is only a large process of wealth creation, and the current poverty alleviation task requires an action mechanism of wealth distribution through finance (Seipel 2003) [6]. Moreover, empirical evidence on the specific mechanism remains sparse; therefore, the paper prepares to use the vulnerability to poverty as a substitute and research the nexus between credit channels and vulnerability to poverty, which can identify the poor more comprehensively and dynamically, and achieve targeted poverty alleviation. Beyond that, quantile regression is further applied to compare the effect difference of credit channels on farm household's vulnerability to poverty according to varying degrees of vulnerability to poverty of farm households in an effort better to achieve the goal of poverty alleviation by financial tools more accurately. Starting from the farm household's credit channel, this paper analyses the impact of private loans and bank credit on farm household vulnerability to poverty, which achieves the goal of comprehensively eliminating poverty and rural financial sustainable development.

This paper contributes to the existing literature on the following two aspects. First of all, we analyze the effects of different credit channels, bank credit and private credit, on vulnerability to poverty of Chinese farm households, which is different from other research works on financial poverty 
reduction. Second, we compare the effect differences of credit channels on poverty alleviation for different levels of vulnerability to poverty. More specifically, we first use the Probit model to evaluate whether bank credit helps farm households reduce the probability of being vulnerable to poverty and whether private credit helps farm households reduce the probability of being vulnerable to poverty. Next, we use quantile regression to test the effect differences of credit channels on vulnerability to poverty for different levels of vulnerability to poverty. Finally, we employ another index of vulnerability to poverty to do a robustness test.

The rest of this paper is organized as follows. Section 2 presents a literature review and research hypothesis; Section 3 discusses the model setting and descriptive statistics; the empirical results and discussion are described in Section 4; finally, Section 5 is conclusions and implications.

\section{Literature Review and Research Hypothesis}

The micro mechanism between financial development and poverty alleviation is mainly reflected in the following aspects: (1) Financial development can improve the ability of farm households to carry out risk management (Gulli 1998; Bakhtiari 2006; Urrea and Maldonado 2011; Choudhury 2014; Maladonado and Gonzalez 2008; Gutierrez et al. 2009; Rooyen et al. 2012; Kinnan and Townsend 2012; Ambrus et al. 2014) [7-15], (2) Smoothing consumption (Bakhtiari 2006; Geda and Shimeless 2006; Liverpool and Winter 2010) $[8,16,17]$, (3) Improving production and living conditions and production capacity (Bakhtiari 2006; Gulli 1998; Barr 2005; Ghazala et al. 2007; Mahjabeen 2008; Liverpool and Winter 2010; Morduch et al. 2002; Karlan and Zinman 2010; Islam and Maitra 2012; Field et al. 2013; Rahman et al. 2015) [18-24], (4) Helping accumulate social capital and improve social status (Mahjabeen 2008), and (5) Increasing income (Remenyi and Quinones 2000; Maladonado and Gonzalez 2008; Gutierrez et al. 2009; Rooyen 2012; Liverpool and Winter 2010; Copestake et al. 2005) [11,13,25-27]. From the aspect of the meso-level, Burgess and Pande (2005) [28] proved that if the number of rural grassroots banking institutions increase by 1 percent, the incidence of rural poverty will reduce by 0.34 percent. The reform and development of the rural banking industry have significantly brought about an increase in output and a decrease in poverty. The empirical studies of Martin et al. (2001) [29], Ravallion and Chen (2007) [30], Beck et al. (2005) [31], and Spiller (2012) [32] all showed that inclusive financial development has a significant impact on poverty alleviation. On the macro level, Bakhtiari (2006) [8] proposed that financial development could promote economic growth and indirectly reduce poverty by improving resource allocation efficiency, cultivating market environment and accelerating the use of new technologies. Li (2018) [33], Jalilian and Kirkpatrick (2002, 2005) [34,35], Dollar and Kraay (2001) [36], Clark, Xu, and Zou (2003) [37], Beck, Demirguc-Kunt and Levine (2004) [38], Jeanneney and Kpodar $(2005,2008)$ [39], Daly and Akhter (2010) [40] proved that financial development can alleviate poverty through economic growth and income distribution and has a positive role in promoting poverty alleviation.

However, some scholars take a different view. Greenwood and Jovanovic (1990) [41] showed that financial development not only affects income distribution but also affects the lives of the poor, resulting in the effect of, first, worsening and then improving the income of the poor. In addition, the dynamic model is used to verify the Kuznets hypothesis; it is found that when the economy is undeveloped, the poor cannot afford the cost of financial service institutions, which leads to the widening gap between the rich and the poor. Therefore, sometimes it is not beneficial to the poor. Aghion and Bolton (1997) [42], Lloyd-Ellis and Bernhardt (2000) [43], Townsend and Ueda $(2003,2006)[44,45]$, Chakraborty and Ray (2007) [46] all verified this view. Galor and Zeira (1993) [47], Ravallion (1997, 2001) [48] thought that when the effect of distributive inequality is sufficient to offset the poverty alleviation effect of economic growth, financial development will be adverse to poverty alleviation.

The direct impact of financial services on poverty alleviation is mainly determined by the poor's participation in and access to financial products and services, and the poverty reduction effects of financial services vary with different accessibility. Additionally, there are also significant differences in the cost of different borrowing channels, so the impact of different borrowing channels on the 
vulnerability to poverty of farm households is quite different. Although there are so many works of literature about how finance influences poverty from micro, medium, and macro perspectives, little has been done to formally explore that different borrowing behaviors affect different types of poor households. Informal borrowing behavior is a way for farmers to cope with risks (Karlan et al. 2009) [49], many farm households participate in informal lending and borrowing behavior as lenders or borrowers (Fafchamps and Gubert 2007; Munshi and Rosenzweig 2016) [50,51], although private borrowing can improve the credit availability of farmers to some extent, and help increase the temporary income of farm household and alleviate poverty. However, the effect of informal risk-sharing has a threshold effect and a regional effect.

$\mathrm{Xu}$ et al. (2016) [52] discussed the impact of private borrowing and lending (zero interest loans between relatives and friends) on the poverty of rural households under the health impact from the aspects of poverty prevalence and vulnerability to poverty and finds that, although private lending and borrowing behaviors alleviate the financial pressure on farm households to cope with health risks and help reduce the poverty prevalence to some extent, it will increase the poverty and vulnerability-to-poverty of farmers in the future. Due to the lack of formal financial risk response mechanisms, informal risk-sharing has become an important means for vulnerable farm households to cope with risks (Kinnan and Townsend 2012; Ambrus et al. 2014) [14,15]. Although the risk-sharing arrangement can help farmers overcome temporary shocks, it is difficult to improve the farm household's sustainable income significantly. It has no significant effect on the persistent poverty of farm households.

Therefore, Hypothesis 1 is put forward:

Hypothesis 1. Informal risk-sharing arrangements have no significant effect on reducing vulnerability to poverty of peasant households.

Imai (2010) [53] examined the relationship between microfinance and household poverty alleviation in India. They found out that productive loans provided by micro-financial institutions show a significant positive effect based on multi-dimensional indicators such as income; this positive effect is significantly greater in rural areas than in urban areas. Sun et al. (2019) [54] also verified that formal borrowing behavior can help increase farm household income. Formal borrowing behavior, on the one hand, has the characteristics of a high threshold; on the other hand, it has a cautious response to risk measures for farm households. It has high repayment demand, so farm household loans only can be used to improve production. Namely, when farm households get formal credit, it promotes their production levels and increases their income and the possibility of being lifted out of poverty.

Therefore, we put forward Hypothesis 2:

Hypothesis 2. Bank credit helps farmers out of poverty and reduces the vulnerability to poverty of farm households.

\section{Data and Methodology}

\subsection{The Data}

China Household Finance Survey data (CHFS) is utilized in the paper to measure the poverty vulnerability of farm households and verify the impact of dual credit channels on farm household vulnerability to poverty. CHFS is a nationally representative household survey conducted by the Survey and Research Centre for China Household Finance of the Southwestern University of Finance and Economics. The first-round survey was conducted in 2011, in which the completed 8438 sample households are located in 320 communities in 80 counties, both rural and urban, all across 25 provinces (please see https://chfs.swufe.edu.cn/zhixingdiaocha.aspx for the detailed information). The second survey was conducted in 2013, in which the sample households increase to 27,775 , 
located in 1048 communities in 262 countries across 29 provinces. The third round survey was continuously carried out in 2015. The whole sampling scheme and the end sampling scheme are mainly adopted following the principle of uniform sample selection. The questionnaire consists of four parts: demographic characteristics, assets and liabilities, insurance and protection, expenditure and income. Through detailed comparison with the data of the National Bureau of Statistics, the survey data of CHFS are highly consistent in demographic characteristics, household income, and other aspects, indicating that the CHFS data are nationally representative.

Considering the implementation of targeted poverty alleviation strategy (in October 2013, General Secretary Xi Jinping put forward the concept of "targeted poverty alleviation" firstly during his investigation in Hunan Province), this paper uses the survey data of 2015 after the implementation of the targeted poverty alleviation strategy. In 2015, the samples of the third-round survey were distributed in 29 provinces (districts and cities), 351 counties (districts and cities), and 1396 village (residential) committees, with a total of 40,000 households as valid samples. In order to ensure the objectivity of the data and maintain the consistency of the data, samples with the interviewed household heads are selected, and the final survey was conducted on 37,289 households, and 133,183 individual pieces of information were collected, among which there were 11,654 households in rural China. These farm households are evenly distributed in the eastern, central, and western regions of the country, including 4294 households in the eastern region, 3955 households in the central region, and 3405 households in the western region.

\subsection{Variables}

\subsubsection{Vulnerability to Poverty Index of Farm Household}

This paper adopts vulnerability as expected poverty (VEP) based on the definition of expected poverty proposed by Chaudhuri et al. (2002) [4]. This means if the probability of poverty in the future exceeds the incidence of poverty, the rural household is defined as a household with vulnerability to poverty. If it is less than the incidence of poverty, the rural household is regarded as a household without vulnerability to poverty. Compared with the traditional poverty, this index is dynamic and forward-looking. In addition, this definition is applicable to the research method for cross-sectional data, which can solve the problem of insufficient data in developing countries, so scholars have widely adopted it in various countries (Chaudhuri et al. 2002) [4]. Under the definition of VEP, this paper uses the method of Chaudhuri et al. (2002) to estimate the probability of future poverty by using the three-stage feasible generalized least squares method FGLS (Amemiya 1997; Chaudhuri et al. 2002) $[4,55]$ under the assumption that the logarithm of per capita annual consumption is a normal distribution. First, OLS is used to estimate household consumption, and the resulting residual is described as follows:

$$
\begin{gathered}
\ln C_{i}=X_{i} \beta+\varepsilon_{i} \\
\hat{\varepsilon}_{\mathrm{i}}^{2}=X_{\mathrm{i}} \theta+\gamma_{\mathrm{i}}
\end{gathered}
$$

where $C_{i}$ represents per capita household consumption, $X_{i}$ is the characteristic variable that affects household consumption per capita, including household head's gender, household head's age, year of education for household head, household head's marital status, household head's health status, total family assets, total family income, family size, dependency ratio. The parameter $\varepsilon_{i}$ is the residual of the household per capita consumption equation, which represents consumption fluctuation. Residual of the consumption equation can be obtained through OLS regression. The family characteristic variable is regressed with a residual square to obtain the estimator $\hat{\theta}_{O L S}$, the residual Equation (2) is deformed with an estimate, OLS regression is carried out again for the deformed model to obtain an effective and progressive FGLS estimator $\hat{\theta}_{F G L S}$, then the consistent estimator of the variance of household 
consumption per capita is obtained. By deforming household per capita consumption equation (1), the effective estimator can be obtained through OLS regression $\hat{\beta}_{F G L S}$.

$$
\begin{gathered}
\frac{\hat{\varepsilon}_{\mathrm{i}}^{2}}{X_{i} \hat{\theta}_{O L S}}=\left[\frac{X_{\mathrm{i}}}{X_{i} \hat{\theta}_{O L S}}\right] \theta+\frac{\gamma_{\mathrm{i}}}{X_{i} \hat{\theta}_{O L S}} \\
\frac{\ln C_{i}}{X_{i} \hat{\theta}_{F G L S}}=\left[\frac{X_{i}}{X_{i} \hat{\theta}_{F G L S}}\right] \beta+\frac{\varepsilon_{i}}{X_{i} \hat{\theta}_{F G L S}}
\end{gathered}
$$

The estimator of $\beta$ and $\theta$ are obtained by FGLS method, and the mean value and variance of future consumption can be directly estimated according to this method:

$$
\begin{gathered}
\mu_{\ln _{\mathrm{C}, t+1}}=\hat{\mathrm{E}}\left[\ln C_{i} \mid X_{\mathrm{i}}\right]=X_{i} \hat{\beta}_{F G L S} \\
\hat{\sigma}_{\ln _{\mathrm{C}, \mathrm{t},+1}^{2}}^{2}=\operatorname{Var}\left[\ln C_{i} \mid X_{\mathrm{i}}\right]=\hat{\sigma}_{\mathrm{e}, \mathrm{i}}^{2}=X_{i} \hat{\theta}_{F G L S}
\end{gathered}
$$

In the estimation of vulnerability to poverty, the poverty line needs to be set. The poverty line in this paper adopts the latest World Bank international poverty line standards of USD 1.9 and USD 3.1 per capita daily consumption, respectively. Adjusted for PPP and CPI, the corresponding poverty lines in 2014 were 2611 Yuan and 4260 Yuan, respectively. The consumption criterion is superior to the traditional income measurement method to measure farm household's vulnerability to poverty: First, poverty cannot be defined by income standards, and income variables cannot be controlled in the regression model, which will lead to relatively serious endogenous problems; second, compared with income data with large measurement errors, consumption data can more accurately reflect family welfare status. According to Equations (5) and (6), the estimation results of logarithm and variance of future consumption of farm households are obtained, and the estimation formula of farm household's vulnerability to poverty is further obtained as follows:

$$
\hat{\mathrm{p}}_{\mathrm{i}}=P\left(\ln C_{i}<\ln \mathrm{z} \mid X_{\mathrm{i}}\right)=\varphi\left(\frac{\ln \mathrm{z}-\mathrm{E}\left[\ln C_{i} \mid X_{\mathrm{i}}\right]}{\sqrt{\operatorname{Var}\left[\ln C_{i} \mid X_{\mathrm{i}}\right]}}\right)=\varphi\left(\frac{\ln \mathrm{z}-X_{i} \hat{\beta}}{\sqrt{X_{i} \hat{\theta}}}\right)
$$

where $\varphi(\cdot)$ is the standard normal distribution function and $\hat{\mathrm{p}}_{\mathrm{i}}$ is the value of the farm household's vulnerability to poverty.

In addition, it is also necessary to set a vulnerability line, which is commonly set according to the poverty incidence rate and the $50 \%$ probability value. The poverty incidence rate is used to set the vulnerability line, that is, when the probability of a family is in poverty in the future is greater than the poverty incidence rate, the family is considered to be the one with vulnerability to poverty. A vulnerability line is set with a probability value of $50 \%$, that is, when the probability of poverty of a family is greater than $50 \%$ in the future, the family is considered to be the one with vulnerability to poverty. However, taking the $50 \%$ probability value as the vulnerability line has a shortcoming, that is, it can only identify the long-term poor families, but will miss the temporary poor families or risk-vulnerable poverty. Some scholars also use the probability value converted by the time-period as the fragile line (Chaudhuri et al. 2002; Skoufias and Quisumbing 2005) [4,5]. Chaudhuri et al. (2002) converted the $50 \%$ probability value of poverty in the next two years as $29 \%$ [4].

\subsubsection{Choosing Credit Channels: Bank Credit and Private Credit}

One of the main explanatory variables in this paper is whether to choose a folk loan. Private credit mainly happens between relatives and friends. If the farm household gets loans from relatives and friends, the farm household chooses private credit. The variable value is 1 ; otherwise, it is 0 .

Another major explanatory variable is whether the farm household chooses bank credit. Choosing bank credit means that the farm household obtains loans from formal financial institutions. It is a market transaction with a standard form of contract, with clear terms of the loan (repayment date), 
interest rate, and amount of loan. Formal financial institutions include the following institutions, in addition to the three main forces of formal financial institutions (rural credit cooperatives, the Agricultural Development Bank of China, and the Agricultural Bank of China), state-owned commercial banks, urban credit cooperatives, joint-stock commercial banks, and the village banks since incremental development in 2007. Moreover, some of the non-bank financial institutions (e.g., small loan companies, leasing companies, trust investment companies, finance companies) also provide, to a certain extent, agriculture financial services. As farm households also have standard contracts when borrowing money from these non-bank financial institutions, they are also regarded as bank credit if farm households borrow money from these institutions. If the farm household has obtained loans from the above departments or institutions, the farm household chooses bank credit, and the value of this variable is set as 1 , otherwise set as 0 .

\subsubsection{Control Variables}

Because the aim of this paper is to study the effect of the credit channel on farm household poverty vulnerability, choosing the control variables must follow principles that are only related to the poverty vulnerability of farm households and has nothing to do with the farm household borrowing channels. With reference to some scholars' studies, control variables have mainly two categories: characteristics of the head of the household and household characteristic variables. The variables of characteristics of the household head include gender, age, age square, years of schooling, marital status, and health status. Household characteristic variables cover family size, household net asset, family income, the dependency ratio, whether to participate in endowment insurance, endowment insurance balance, whether to participate in medical insurance, and medical insurance balance (see Table 1).

\subsection{Model Specification}

The purpose of this paper is to compare the impact of binary credit channels on vulnerability to poverty of farm households under different poverty levels. However, traditional OLS methods can only measure the influence of explanatory variables on the average expected value of explained variables. They cannot directly analyze how the influence of whether farm households participate in formal borrowing behavior (or informal borrowing behavior) on vulnerability to poverty of farm household changes with the change of poverty degree. Therefore, the quantile regression method (QR) is used in this paper to estimate the impact of participating in formal or informal borrowing behavior for farm households on their vulnerability to poverty. The quantile regression model is as follows:

$$
\operatorname{Quant}_{\theta}\left(\mathrm{p}_{\mathrm{i}} \mid X_{\mathrm{i}}\right)=\beta^{\theta} X_{\mathrm{i}}
$$

In the model, Quant ${ }_{\theta}\left(\mathrm{p}_{\mathrm{i}} \mid X_{\mathrm{i}}\right)$ denotes conditional quantile function for vulnerability to poverty of farm household $\mathrm{p}_{\mathrm{i}}$ under the given independent variable $X_{\mathrm{i}}$ and quantile $\theta$. Quantile regression minimizes the sum of weighted residuals absolute values, which is different from the sample mean regression that minimizes the sum of squared residuals, namely

$$
\min \left\{\sum_{i, p_{i} \geq \delta} \theta\left|p_{i}-\delta\right|+\sum_{i, p_{i}<\delta}(1-\theta)\left|p_{i}-\delta\right|\right\}, \quad \delta=X_{\mathrm{i}} \beta
$$

Farm household vulnerability to poverty is taken as a dependent variable; based on the OLS influence regression of choosing informal or formal borrowing for farm households on vulnerability to poverty of farm households, representative quantiles are selected. Heterogeneous impacts of participating in formal borrowing behavior on vulnerability to poverty of farm households in different quantiles are considered by quantile regression, and the different effects of participating in informal borrowing behavior on vulnerability to poverty of farm households in different quantiles are also examined by quantile regression. 
Table 1. Definition and statistical analysis of each variable.

\begin{tabular}{|c|c|c|c|c|c|}
\hline Variables & Definition & Mean & Std. Dev. & Min & Max \\
\hline InC & The logarithm of household consumption per capita & 8.802 & 0.858 & 3.912 & 12.925 \\
\hline Bank credit & $1=$ the farm household has a loan from an formal source, $0=$ otherwise & 0.100 & 0.300 & 0 & 1 \\
\hline Private credit & $1=$ the farm household has a loan from an informal source, $0=$ otherwise & 0.332 & 0.471 & 0 & 1 \\
\hline \multicolumn{6}{|l|}{ Characteristics of household head } \\
\hline Male & $1=$ male, $0=$ female & 0.878 & 0.327 & 0 & 1 \\
\hline Age & Current age in 2015 & 55.687 & 12.542 & 3 & 99 \\
\hline Age $^{2}$ & & 3258.276 & 1418.149 & 9 & 9801 \\
\hline Year of schooling & $\begin{array}{c}0=\text { no educating, } 6=\text { primary, } 9=\text { junior high school, } 12=\text { senior high school, } 13= \\
\text { Secondary school/vocational high school, } 15=\text { college, } 16=\text { Bachelor, } 19=\text { master, } \\
23=\text { doctor }\end{array}$ & 6.965 & 3.487 & 0 & 16 \\
\hline Marriage & $0=$ single, $1=$ married & 0.887 & 0.316 & 0 & 1 \\
\hline Health & $0=$ poor healthy, $1=$ neither good nor bad, $2=$ healthy & 1.124 & 0.770 & 0 & 2 \\
\hline \multicolumn{6}{|l|}{ Household characteristics } \\
\hline Family size & The number of household members & 4.116 & 1.937 & 1 & 19 \\
\hline Dependency ratio & The proportion of family members aged 14 or below and 65 or above & 0.314 & 0.306 & 0 & 1 \\
\hline Total family income & Total family income ${ }^{*} 10^{-5}(10,000$ Yuan) & 0.427 & 1.139 & -8 & 50 \\
\hline Total family assets & Total family assets* $10^{-5}$ (10,000 Yuan) & 3.292 & 7.950 & 0 & 200 \\
\hline Endowment insurance participation & $1=$ participating in endowment insurance, $0=$ otherwise & 0.920 & 0.271 & 0 & 1 \\
\hline Endowment insurance balance & Endowment insurance balance of that year (10,000 Yuan) & 0.146 & 0.664 & 0 & 16.146 \\
\hline Medical insurance participation & $1=$ participating in medical insurance $0=$ otherwise & 0.951 & 0.216 & 0 & 1 \\
\hline Medical insurance balance & Medical insurance balance of the year (10,000 Yuan) & 0.023 & 0.180 & 0 & 9.050 \\
\hline
\end{tabular}




\subsection{Descriptive Statistics Analysis}

We employed Stata 13.0 to verify the nexus. Firstly, through the statistical analysis of each variable of 11,654 survey samples, the logarithm mean of the per capita consumption amount of farm households is 8.802 . Male household heads account for $87.8 \%$ of the total sample, the average age of a household head is 55.687 years old, the average educational level of the household head is between the primary school graduation and the first year of junior high school, the head of household is married (accounting for $88.7 \%$ ), and the average health status is between "neither good nor bad" and "healthy". The average family size is 4.116 , and the average dependency ratio of households is $31.4 \%$. The average family income is 42,700 Yuan, and the average family assets amount to 329,200 Yuan. The average proportions of households participating in medical insurance and endowment insurance are $95.1 \%$ and $92 \%$, respectively. In rural China, endowment insurance and medical insurance are basically fully covered, and the balances of medical insurance and endowment insurance are 230 and 1460 Yuan, respectively (see Table 1 ).

\section{Empirical Results and Discussions}

\subsection{Regional Differences of Farm Household's Vulnerability to Poverty in China}

Taking the poverty prevalence as the vulnerability line, when the poverty line is set at USD 1.90 per person per day, the rate of rural household vulnerability to poverty is 0.164 . When the poverty line is set at USD 3.10 per person per day, the average rate of whole rural household vulnerability to poverty is 0.286 . When the poverty line is increased by 63 percent, the rate of farm household vulnerability to poverty increases to 74.39 percent. The rate of households with vulnerability to poverty rises with the poverty standard. From the differences between the eastern, central, and western region of China, if the poverty standard is USD 1.90, the rate of farm households with vulnerability to poverty in the western region is the highest, followed by the eastern region; the rate of farm household with vulnerability to poverty in the central region is the lowest. If the per capita consumption line of USD 3.10 is taken as the poverty standard, the rate of farm households with vulnerability to poverty is still ranked as the western region, eastern region, and central region from the highest to the lowest. However, if vulnerability to poverty line is increased to 29 percent of probability (both the poverty line of USD 1.90 and the poverty line of USD 3.10), the rate of farm households with vulnerability to poverty in the eastern region is the highest. When vulnerability to poverty line is further raised to 50 percent, the rate of farm households with vulnerability to poverty is still the highest in the eastern region (see Table 2). Therefore, by raising the poverty line standard, the rate of farm households with vulnerability to poverty increases. With the increase of vulnerability to the poverty line, the rate of farm households with vulnerability to poverty decreases. According to the horizontal comparison of the poverty line, the structural poverty proportion in the western region is relatively large, while the risk poverty proportion in the eastern region is comparatively large. (Structural vulnerability means that the per capita consumption level of farm households in the future is below the poverty line. According to the characteristics of the normal distribution function, farm household vulnerability to poverty is greater than $50 \%$. In contrast, risk vulnerability means that although the per capita consumption level of a farm household in the future is higher than the poverty line, vulnerability to poverty is caused by excessive consumption fluctuation.) 
Table 2. Regional difference of farm household vulnerability to poverty (unit: percent).

\begin{tabular}{|c|c|c|c|c|c|c|}
\hline & \multicolumn{2}{|c|}{$\begin{array}{l}\text { Poverty Prevalence (The Total } \\
\text { Number of Poor in China is } \\
70.17 \text { Million; the Poverty } \\
\text { Incidence was } 7.2 \% \text { in } 2014 \text { ) }\end{array}$} & \multicolumn{2}{|c|}{ Probability Value $=29 \%$} & \multicolumn{2}{|c|}{ Probability Value $=\mathbf{5 0} \%$} \\
\hline & $\begin{array}{c}\text { (1) } \\
\text { USD } 1.90\end{array}$ & $\begin{array}{c}(2) \\
\text { USD } 3.10\end{array}$ & $\begin{array}{c}\text { (3) } \\
\text { USD } 1.90\end{array}$ & $\begin{array}{c}\text { (4) } \\
\text { USD } 3.10\end{array}$ & $\begin{array}{c}\text { (5) } \\
\text { USD } 1.90\end{array}$ & $\begin{array}{c}\text { (6) } \\
\text { USD } 3.10\end{array}$ \\
\hline Eastern region & 0.177 & 0.283 & 0.132 & 0.161 & 0.120 & 0.137 \\
\hline Central region & 0.139 & 0.255 & 0.097 & 0.125 & 0.087 & 0.102 \\
\hline Western region & 0.178 & 0.325 & 0.121 & 0.156 & 0.108 & 0.128 \\
\hline $\begin{array}{l}\text { The whole } \\
\text { country }\end{array}$ & 0.164 & 0.286 & 0.117 & 0.147 & 0.105 & 0.123 \\
\hline
\end{tabular}

\subsection{The Impact of Private Credit on Farm Household's Vulnerability to Poverty}

From the regression results in the first column of Table 3, it can be seen that when the poverty standard is USD 1.9 per capita per day, farm household vulnerability to poverty with folk loans is $0.2 \%$ higher than that of households without private credit; however, this is not significant.

Table 3. The Quantile regression of the effect of private credit on farm household vulnerability to poverty (poverty standard: USD 1.90).

\begin{tabular}{|c|c|c|c|c|}
\hline & OLS-1 & $\theta=0.25$ & $\theta=0.50$ & $\theta=0.75$ \\
\hline Private credit & $\begin{array}{c}0.002 \\
(0.002)\end{array}$ & $\begin{array}{c}0.000 \\
(0.000)\end{array}$ & $\begin{array}{c}0.000 \\
(0.000)\end{array}$ & $\begin{array}{c}0.000 \\
(0.000)\end{array}$ \\
\hline Male & $\begin{array}{c}-0.022 * * * \\
(0.002)\end{array}$ & $\begin{array}{c}-0.002 * * * \\
(0.000)\end{array}$ & $\begin{array}{c}-0.002 \text { *** } \\
(0.001)\end{array}$ & $\begin{array}{c}-0.005^{* * *} \\
(0.001)\end{array}$ \\
\hline Age & $\begin{array}{c}-0.021^{* * *} \\
(0.000)\end{array}$ & $\begin{array}{c}-0.004 * * * \\
(0.000)\end{array}$ & $\begin{array}{c}-0.005 * * * \\
(0.000)\end{array}$ & $\begin{array}{c}-0.010 * * * \\
(0.001)\end{array}$ \\
\hline $\mathrm{Age}^{2}$ & $\begin{array}{l}0.000^{* * * *} \\
(0.000)\end{array}$ & $\begin{array}{c}0.000^{* * *} \\
(0.000)\end{array}$ & $\begin{array}{c}0.000^{* * *} \\
(0.000)\end{array}$ & $\begin{array}{c}0.000 * * * \\
(0.000)\end{array}$ \\
\hline Year of schooling & $\begin{array}{c}0.001^{* * * *} \\
(0.000)\end{array}$ & $\begin{array}{l}-0.000 \\
(0.000)\end{array}$ & $\begin{array}{c}0.000 \\
(0.000)\end{array}$ & $\begin{array}{c}0.000 * * * \\
(0.000)\end{array}$ \\
\hline Marriage & $\begin{array}{c}0.090^{* * * *} \\
(0.002)\end{array}$ & $\begin{array}{c}0.023^{* * *} \\
(0.002)\end{array}$ & $\begin{array}{c}0.015^{* * *} \\
(0.001)\end{array}$ & $\begin{array}{c}0.010 * * * \\
(0.001)\end{array}$ \\
\hline Health & $\begin{array}{c}-0.018^{* * *} \\
(0.001)\end{array}$ & $\begin{array}{c}-0.007^{* * *} \\
(0.000)\end{array}$ & $\begin{array}{c}-0.008^{* * *} \\
(0.000)\end{array}$ & $\begin{array}{c}-0.009^{* * * *} \\
(0.000)\end{array}$ \\
\hline Family size & $\begin{array}{c}0.015^{* * * *} \\
(0.000)\end{array}$ & $\begin{array}{c}0.003^{* * *} \\
(0.000)\end{array}$ & $\begin{array}{c}0.004^{* * *} \\
(0.000)\end{array}$ & $\begin{array}{c}0.006^{* * *} \\
(0.000)\end{array}$ \\
\hline Dependency ratio & $\begin{array}{c}0.051^{* * * *} \\
(0.003)\end{array}$ & $\begin{array}{c}0.015^{* * *} \\
(0.001)\end{array}$ & $\begin{array}{c}0.017^{* * *} \\
(0.001)\end{array}$ & $\begin{array}{c}0.022^{* * *} \\
(0.001)\end{array}$ \\
\hline Total family income & $\begin{array}{c}-0.007^{* * *} \\
(0.001)\end{array}$ & $\begin{array}{c}-0.004^{* * *} \\
(0.000)\end{array}$ & $\begin{array}{c}-0.004^{* * *} \\
(0.000)\end{array}$ & $\begin{array}{c}-0.003^{* * *} \\
(0.000)\end{array}$ \\
\hline Total family assets & $\begin{array}{c}-0.001 * * * \\
(0.000)\end{array}$ & $\begin{array}{c}-0.000 * * * \\
(0.000)\end{array}$ & $\begin{array}{c}-0.000 * * * \\
(0.000)\end{array}$ & $\begin{array}{c}-0.000 * \\
(0.000)\end{array}$ \\
\hline Endowment insurance participation & $\begin{array}{c}-0.875^{* * *} \\
(0.000)\end{array}$ & $\begin{array}{c}-0.889 * * * \\
(0.006)\end{array}$ & $\begin{array}{c}-0.947^{* * *} \\
(0.001)\end{array}$ & $\begin{array}{c}-0.970 \text { *** } \\
(0.002)\end{array}$ \\
\hline Endowment insurance balance & $\begin{array}{c}0.000 \\
(0.000)\end{array}$ & $\begin{array}{c}0.000^{* * *} \\
(0.000)\end{array}$ & $\begin{array}{l}0.000 \text { * } \\
(0.000)\end{array}$ & $\begin{array}{c}0.000 * * * \\
(0.000)\end{array}$ \\
\hline Medical insurance participation & $\begin{array}{c}-0.128^{* * *} \\
(0.003)\end{array}$ & $\begin{array}{c}-0.037^{* * *} \\
(0.003)\end{array}$ & $\begin{array}{c}-0.055^{* * *} \\
(0.001)\end{array}$ & $\begin{array}{c}-0.120 * * * \\
(0.013)\end{array}$ \\
\hline Medical insurance balance & $\begin{array}{c}-0.001 \text { *** } \\
(0.000)\end{array}$ & $\begin{array}{c}-0.002 * * * \\
(0.000)\end{array}$ & $\begin{array}{c}-0.000 * * * \\
(0.000)\end{array}$ & $\begin{array}{c}-0.000 * \\
(0.000)\end{array}$ \\
\hline Constant & $\begin{array}{l}1.453^{* * *} \\
(0.013)\end{array}$ & $\begin{array}{l}1.006^{* * *} \\
(0.007)\end{array}$ & $\begin{array}{c}1.131^{* * *} \\
(0.003)\end{array}$ & $\begin{array}{c}1.343^{* * *} \\
(0.019)\end{array}$ \\
\hline
\end{tabular}

Notes: ${ }^{* * *}, * *, *$ showing significance at $1 \%, 5 \%$, and $10 \%$ probability levels, respectively; standard errors are in parenthesis. 
Farm household vulnerability to poverty where the family head is a man is lower than that of a household whose family head is a woman. The influence of age on farm household vulnerability to poverty presents a positive u-shape; when a farm household does not reach a certain age value, farm household vulnerability to poverty decreases with the increase of age, and, after reaching this peak value, farm household vulnerability to poverty increases with the increase of age. The married household head's vulnerability to poverty is higher than that of the unmarried household head. With better health, vulnerability to poverty will be reduced, which is consistent with the more typical phenomenon of "poverty caused by disease and poverty returned due to disease" in rural areas. Increasing the size of a family increases a family's vulnerability to poverty. If the dependency ratio increases by one unit, the farm household's vulnerability to poverty will increase by $5.1 \%$ significantly, and the number of children and the elderly will increase farm household vulnerability to poverty. The increase of total family income level or total family assets will reduce farm household vulnerability to poverty. Participation in endowment insurance or medical insurance will also reduce farm household vulnerability to poverty.

By comparing the quantile regression results of the impact of informal borrowing behavior on farm household vulnerability to poverty in Columns (2) to (4), it can also be seen that informal borrowing behavior makes it difficult to reduce farm household vulnerability to poverty, which is consistent with Hypothesis 1 above.

\subsection{The Effect of Bank Credit on Farm Household Vulnerability to Poverty}

According to the regression results of Column 1 in Table 4, the bank credit of farm households has a negative impact on farm household vulnerability to poverty; participation in bank credit is conducive to the reduction of farm household vulnerability to poverty. Similarly, a household with a male head is less vulnerable to poverty than that with a female head. The relationship between age and poverty vulnerability of farm households presents a positive u-shaped relationship; before a certain age, farm household vulnerability to poverty decreases with the increase of age, but after this age, farm household vulnerability to poverty increases with the increase of age. The number of years of education will increase farm household vulnerability to poverty, which may be different from the results of other studies on the effect of human capital. However, for rural families, education cost is a large expenditure, so the increase in education level will aggravate the poverty degree of farm households. Married farm households are more vulnerable to poverty than single farm households. As health improves by one unit, farm household vulnerability to poverty decreases by $1.9 \%$. As the family size for farm households grows by one unit, the vulnerability to poverty will increase by $1.5 \%$. Farm household vulnerability to poverty increases with an increase in the dependency ratio. The increase of total family income and total family assets can reduce farm household vulnerability to poverty. Buying medical insurance or endowment insurance can also reduce farm household vulnerability to poverty.

Regression results of $25 \%, 50 \%$, and $75 \%$ of the points on the effect of bank credit on farm household vulnerability to poverty all show that participation in formal borrowing behavior can help reduce farm household vulnerability to poverty, which verifies the content of Hypothesis 2 above. 
Table 4. The quantile regression of the effect of bank credit on farm household vulnerability to poverty (poverty standard: \$1.90).

\begin{tabular}{|c|c|c|c|c|}
\hline & OLS-1 & $\theta=0.25$ & $\theta=0.50$ & $\theta=0.75$ \\
\hline Bank credit & $\begin{array}{c}-0.004 * \\
(0.002)\end{array}$ & $\begin{array}{c}-0.000 \text { ** } \\
(0.000)\end{array}$ & $\begin{array}{c}-0.000 \text { ** } \\
(0.001)\end{array}$ & $\begin{array}{c}-0.001 \text { ** } \\
(0.000)\end{array}$ \\
\hline Male & $\begin{array}{c}-0.022 * * * \\
(0.002)\end{array}$ & $\begin{array}{c}-0.002^{* * *} \\
(0.000)\end{array}$ & $\begin{array}{c}-0.002 * * * \\
(0.001)\end{array}$ & $\begin{array}{c}-0.005^{* * *} \\
(0.000)\end{array}$ \\
\hline Age & $\begin{array}{c}-0.021^{* * * *} \\
(0.000)\end{array}$ & $\begin{array}{c}-0.004^{* * *} \\
(0.000)\end{array}$ & $\begin{array}{c}-0.005^{* * *} \\
(0.000)\end{array}$ & $\begin{array}{c}-0.010 * * * \\
(0.001)\end{array}$ \\
\hline Age2 & $\begin{array}{c}0.000^{* * *} \\
(0.000)\end{array}$ & $\begin{array}{c}0.000^{* * *} \\
(0.000)\end{array}$ & $\begin{array}{c}0.000^{* * *} \\
(0.000)\end{array}$ & $\begin{array}{c}0.000^{* * *} \\
(0.000)\end{array}$ \\
\hline Year of schooling & $\begin{array}{c}0.001^{* * *} \\
(0.000)\end{array}$ & $\begin{array}{c}-0.000 * * \\
(0.000)\end{array}$ & $\begin{array}{c}0.000 \\
(0.000)\end{array}$ & $\begin{array}{c}0.000 * * * \\
(0.000)\end{array}$ \\
\hline Marriage & $\begin{array}{c}0.090^{* * *} \\
(0.002)\end{array}$ & $\begin{array}{c}0.023^{* * *} \\
(0.001)\end{array}$ & $\begin{array}{c}0.015^{* * *} \\
(0.001)\end{array}$ & $\begin{array}{c}0.010^{* * *} \\
(0.001)\end{array}$ \\
\hline Health & $\begin{array}{c}-0.019^{* * *} \\
(0.001)\end{array}$ & $\begin{array}{c}-0.007^{* * *} \\
(0.000)\end{array}$ & $\begin{array}{c}-0.008^{* * *} \\
(0.000)\end{array}$ & $\begin{array}{c}-0.009 * * * \\
(0.000)\end{array}$ \\
\hline Family size & $\begin{array}{c}0.015^{* * *} \\
(0.000)\end{array}$ & $\begin{array}{c}0.003^{* * *} \\
(0.000)\end{array}$ & $\begin{array}{c}0.004^{* * *} \\
(0.000)\end{array}$ & $\begin{array}{c}0.006^{* * *} \\
(0.000)\end{array}$ \\
\hline dependency ratio & $\begin{array}{c}0.051^{* * *} \\
(0.003)\end{array}$ & $\begin{array}{c}0.015^{* * *} \\
(0.000)\end{array}$ & $\begin{array}{c}0.017^{* * *} \\
(0.001)\end{array}$ & $\begin{array}{c}0.022^{* * *} \\
(0.001)\end{array}$ \\
\hline Total family income & $\begin{array}{c}-0.007^{* * *} \\
(0.001)\end{array}$ & $\begin{array}{c}-0.004^{* * *} \\
(0.000)\end{array}$ & $\begin{array}{c}-0.004^{* * *} \\
(0.000)\end{array}$ & $\begin{array}{c}-0.003^{* * *} \\
(0.000)\end{array}$ \\
\hline Total family assets & $\begin{array}{c}-0.000^{* * *} \\
(0.000)\end{array}$ & $\begin{array}{c}-0.000^{* * *} \\
(0.000)\end{array}$ & $\begin{array}{c}-0.000^{* * * *} \\
(0.000)\end{array}$ & $\begin{array}{c}-0.000^{* *} \\
(0.000)\end{array}$ \\
\hline Endowment insurance participation & $\begin{array}{c}-0.875^{* * *} \\
(0.003)\end{array}$ & $\begin{array}{c}-0.889^{* * *} \\
(0.005)\end{array}$ & $\begin{array}{c}-0.946^{* * * *} \\
(0.001)\end{array}$ & $\begin{array}{c}-0.970 * * * \\
(0.002)\end{array}$ \\
\hline Endowment insurance balance & $\begin{array}{c}0.000 \\
(0.000)\end{array}$ & $\begin{array}{c}0.000^{* * *} \\
(0.000)\end{array}$ & $\begin{array}{l}0.000 \text { * } \\
(0.000)\end{array}$ & $\begin{array}{c}0.000 * * * \\
(0.000)\end{array}$ \\
\hline Medical insurance participation & $\begin{array}{c}-0.128^{* * *} \\
(0.003)\end{array}$ & $\begin{array}{c}-0.037^{* * * *} \\
(0.003)\end{array}$ & $\begin{array}{c}-0.055^{* * * *} \\
(0.001)\end{array}$ & $\begin{array}{c}-0.120^{* * *} \\
(0.011)\end{array}$ \\
\hline Medical insurance balance & $\begin{array}{c}-0.001^{* * *} \\
(0.000)\end{array}$ & $\begin{array}{c}-0.002 * * * \\
(0.000)\end{array}$ & $\begin{array}{c}-0.000^{* * * *} \\
(0.000)\end{array}$ & $\begin{array}{c}-0.000 \text { ** } \\
(0.000)\end{array}$ \\
\hline Constant & $\begin{array}{c}1.454^{* * *} \\
(0.013)\end{array}$ & $\begin{array}{c}1.005^{* * *} \\
(0.007)\end{array}$ & $\begin{array}{c}1.131^{* * *} \\
(0.003)\end{array}$ & $\begin{array}{c}1.344^{* * *} \\
(0.016)\end{array}$ \\
\hline
\end{tabular}

Notes: ${ }^{* * *},{ }^{* *},{ }^{*}$ showing significance at $1 \%, 5 \%$, and $10 \%$ probability levels, respectively; standard errors are in parenthesis.

\subsection{Robustness Test}

There may be a reverse causality relationship between farm household vulnerability to poverty and credit channels, namely, credit channels may be associated with poverty, but this article is to explain a variable for farm household vulnerability to poverty-rural household's poverty status sometime in the future-which is difficult to connect with existing borrowing channels; therefore, the endogenous problem that results from reverse causality can be ruled out.

In this paper, a more rigorous poverty line standard is selected for regression estimation, namely, the international poverty standard of USD 3.1 per capita consumption, to verify whether the above conclusion is correct or not. Table 5 shows the quantile regression results of the impact of private credit on farm household's vulnerability to poverty when the poverty standard is defined as USD 3.1 per capita consumption. Household vulnerability to poverty with a folk loan is $0.1 \%$ higher than that of households without private credit; however, the results are still not significant. As mentioned before, raising the poverty line can make farm household vulnerability to poverty increase, namely, when the vulnerability to poverty rises, the nexus between private credit and vulnerability to poverty is still consistent with the previous estimate. 
Table 5. The quantile regression of the effect of private credit on farm household vulnerability to poverty (poverty standard: USD 3.1).

\begin{tabular}{|c|c|c|c|c|}
\hline & OLS-1 & $\theta=0.25$ & $\theta=0.50$ & $\theta=0.75$ \\
\hline Private credit & $\begin{array}{c}0.001 \\
(0.002)\end{array}$ & $\begin{array}{c}0.000 \\
(0.000)\end{array}$ & $\begin{array}{c}0.000 \\
(0.001)\end{array}$ & $\begin{array}{l}-0.000 \\
(0.001)\end{array}$ \\
\hline Male & $\begin{array}{c}-0.034^{* * * *} \\
(0.003)\end{array}$ & $\begin{array}{c}-0.011^{* * *} \\
(0.001)\end{array}$ & $\begin{array}{c}-0.014^{* * * *} \\
(0.001)\end{array}$ & $\begin{array}{c}-0.020 * * * \\
(0.001)\end{array}$ \\
\hline Age & $\begin{array}{c}-0.037^{* * * *} \\
(0.001)\end{array}$ & $\begin{array}{c}-0.012^{* * *} \\
(0.000)\end{array}$ & $\begin{array}{c}-0.016^{* * *} \\
(0.000)\end{array}$ & $\begin{array}{c}-0.030^{* * * *} \\
(0.002)\end{array}$ \\
\hline Age $^{2}$ & $\begin{array}{c}0.000^{* * *} \\
(0.000)\end{array}$ & $\begin{array}{c}0.000^{* * *} \\
(0.000)\end{array}$ & $\begin{array}{c}0.000 * * * \\
(0.000)\end{array}$ & $\begin{array}{c}0.000 * * * \\
(0.000)\end{array}$ \\
\hline Year of schooling & $\begin{array}{c}0.002 * * * \\
(0.000)\end{array}$ & $\begin{array}{c}0.000^{* * *} \\
(0.000)\end{array}$ & $\begin{array}{c}0.001^{* * *} \\
(0.000)\end{array}$ & $\begin{array}{c}0.001^{* * *} \\
(0.000)\end{array}$ \\
\hline Marriage & $\begin{array}{c}0.115^{* * *} \\
(0.003)\end{array}$ & $\begin{array}{c}0.075^{* * *} \\
(0.003)\end{array}$ & $\begin{array}{c}0.051^{* * *} \\
(0.001)\end{array}$ & $\begin{array}{c}0.032^{* * *} \\
(0.003)\end{array}$ \\
\hline Health & $\begin{array}{c}-0.034^{* * *} \\
(0.001)\end{array}$ & $\begin{array}{c}-0.020^{* * *} \\
(0.000)\end{array}$ & $\begin{array}{c}-0.021^{* * *} \\
(0.001)\end{array}$ & $\begin{array}{c}-0.021^{* * *} \\
(0.001)\end{array}$ \\
\hline Family size & $\begin{array}{c}0.030^{* * *} \\
(0.000)\end{array}$ & $\begin{array}{c}0.011^{* * * *} \\
(0.000)\end{array}$ & $\begin{array}{c}0.014^{* * *} \\
(0.000)\end{array}$ & $\begin{array}{c}0.020 * * * \\
(0.000)\end{array}$ \\
\hline dependency ratio & $\begin{array}{c}0.073^{* * *} \\
(0.003)\end{array}$ & $\begin{array}{c}0.040 * * * \\
(0.001)\end{array}$ & $\begin{array}{c}0.043^{* * *} \\
(0.002)\end{array}$ & $\begin{array}{c}0.056^{* * *} \\
(0.003)\end{array}$ \\
\hline Total family income & $\begin{array}{c}-0.013^{* * *} \\
(0.002)\end{array}$ & $\begin{array}{c}-0.010^{* * *} \\
(0.000)\end{array}$ & $\begin{array}{c}-0.011^{* * *} \\
(0.001)\end{array}$ & $\begin{array}{c}-0.010 * * * \\
(0.0010)\end{array}$ \\
\hline Total family assets & $\begin{array}{c}-0.001^{* * *} \\
(0.000)\end{array}$ & $\begin{array}{c}-0.001 * * * \\
(0.0001)\end{array}$ & $\begin{array}{c}-0.001^{* * *} \\
(0.000)\end{array}$ & $\begin{array}{c}-0.001 * * * \\
(0.000)\end{array}$ \\
\hline Endowment insurance participation & $\begin{array}{c}-0.900^{* * *} \\
(0.003)\end{array}$ & $\begin{array}{c}-0.925^{* * *} \\
(0.003)\end{array}$ & $\begin{array}{c}-0.949 * * * \\
(0.001)\end{array}$ & $\begin{array}{c}-0.964^{* * *} \\
(0.002)\end{array}$ \\
\hline Endowment insurance balance & $\begin{array}{c}0.000 \\
(0.000)\end{array}$ & $\begin{array}{c}0.000 * * * \\
(0.000)\end{array}$ & $\begin{array}{l}0.000 * * \\
(0.000)\end{array}$ & $\begin{array}{c}0.000 * * * \\
(0.000)\end{array}$ \\
\hline Medical insurance participation & $\begin{array}{c}-0.192^{* * *} \\
(0.004)\end{array}$ & $\begin{array}{c}-0.070^{* * *} \\
(0.004)\end{array}$ & $\begin{array}{c}-0.125^{* * * *} \\
(0.002)\end{array}$ & $\begin{array}{c}-0.242^{* * *} \\
(0.015)\end{array}$ \\
\hline Medical insurance balance & $\begin{array}{c}-0.003^{* * *} \\
(0.000)\end{array}$ & $\begin{array}{c}-0.007^{* * *} \\
(0.001)\end{array}$ & $\begin{array}{c}-0.002 * * * \\
(0.000)\end{array}$ & $\begin{array}{c}-0.001^{* * *} \\
(0.000)\end{array}$ \\
\hline Constant & $\begin{array}{c}1.953^{* * *} \\
(0.015)\end{array}$ & $\begin{array}{c}1.272^{* * * *} \\
(0.010)\end{array}$ & $\begin{array}{c}1.465^{* * *} \\
(0.007)\end{array}$ & $\begin{array}{c}1.971^{* * *} \\
(0.046)\end{array}$ \\
\hline
\end{tabular}

Notes: ${ }^{* * *}, * *, *$ showing significance at $1 \%, 5 \%$, and $10 \%$ probability levels, respectively; standard errors are in parenthesis.

According to Table 6, farm household vulnerability to poverty with bank credit is $0.9 \%$ lower than that of households without bank credit; that is, bank credit can help reduce farm household's vulnerability to poverty. Through quantile regression, we found when the farm household vulnerability to poverty is $25 \%$, farm household vulnerability to poverty with bank credit is $0.03 \%$ lower than that of farm households without bank credit. For the study of farm households whose vulnerability to poverty is $75 \%$, farm household vulnerability to poverty with bank credit is $0.359 \%$ lower than that of farm households without bank credit. Farm household with higher vulnerability to poverty is more likely to reduce vulnerability to poverty through bank credit. Comparing with the estimation before, when the vulnerability to poverty increases, the influence coefficient of bank credit on farm household vulnerability to poverty becomes bigger; when farm household vulnerability to poverty is higher, the effect of vulnerability to poverty alleviation is stronger, which is consistent with the conclusion in the full text, indicating that the conclusion is robust. 
Table 6. The quantile regression of the effect of bank credit on farm household vulnerability to poverty (poverty standard: USD 3.1).

\begin{tabular}{|c|c|c|c|c|}
\hline & OLS-1 & $\theta=0.25$ & $\theta=0.50$ & $\theta=0.75$ \\
\hline Bank credit & $\begin{array}{c}-0.009^{* * *} \\
(0.003)\end{array}$ & $\begin{array}{c}-0.000 * \\
(0.000)\end{array}$ & $\begin{array}{c}-0.001 \text { ** } \\
(0.001)\end{array}$ & $\begin{array}{c}-0.004^{* * *} \\
(0.0010)\end{array}$ \\
\hline Male & $\begin{array}{c}-0.034^{* * *} \\
(0.003)\end{array}$ & $\begin{array}{c}-0.011^{* * *} \\
(0.001)\end{array}$ & $\begin{array}{c}-0.014^{* * *} \\
(0.001)\end{array}$ & $\begin{array}{c}-0.020 * * * \\
(0.002)\end{array}$ \\
\hline Age & $\begin{array}{c}-0.037^{* * * *} \\
(0.001)\end{array}$ & $\begin{array}{c}-0.013^{* * *} \\
(0.000)\end{array}$ & $\begin{array}{c}-0.016^{* * *} \\
(0.000)\end{array}$ & $\begin{array}{c}-0.030 * * * \\
(0.001)\end{array}$ \\
\hline $\mathrm{Age}^{2}$ & $\begin{array}{c}0.000^{* * * *} \\
(0.000)\end{array}$ & $\begin{array}{c}0.000^{* * *} \\
(0.000)\end{array}$ & $\begin{array}{c}0.000^{* * *} \\
(0.000)\end{array}$ & $\begin{array}{c}0.000^{* * *} \\
(0.000)\end{array}$ \\
\hline Year of schooling & $\begin{array}{c}0.002 * * * \\
(0.000)\end{array}$ & $\begin{array}{c}0.000^{* * *} \\
(0.000)\end{array}$ & $\begin{array}{c}0.001^{* * *} \\
(0.000)\end{array}$ & $\begin{array}{c}0.001^{* * *} \\
(0.000)\end{array}$ \\
\hline Marriage & $\begin{array}{c}0.115^{* * *} \\
(0.003)\end{array}$ & $\begin{array}{c}0.075^{* * *} \\
(0.004)\end{array}$ & $\begin{array}{c}0.051^{* * *} \\
(0.001)\end{array}$ & $\begin{array}{c}0.032^{* * *} \\
(0.002)\end{array}$ \\
\hline Health & $\begin{array}{c}-0.034^{* * *} \\
(0.001)\end{array}$ & $\begin{array}{c}-0.020^{* * *} \\
(0.000)\end{array}$ & $\begin{array}{c}-0.021^{* * *} \\
(0.000)\end{array}$ & $\begin{array}{c}-0.021^{* * *} \\
(0.000)\end{array}$ \\
\hline Family size & $\begin{array}{c}0.030 * * * \\
(0.000)\end{array}$ & $\begin{array}{c}0.011^{* * *} \\
(0.000)\end{array}$ & $\begin{array}{c}0.014^{* * *} \\
(0.000)\end{array}$ & $\begin{array}{c}0.020 * * * \\
(0.000)\end{array}$ \\
\hline Dependency ratio & $\begin{array}{c}0.074^{* * *} \\
(0.003)\end{array}$ & $\begin{array}{c}0.040^{* * *} \\
(0.001)\end{array}$ & $\begin{array}{c}0.043^{* * *} \\
(0.002)\end{array}$ & $\begin{array}{c}0.056^{* * *} \\
(0.003)\end{array}$ \\
\hline Total family income & $\begin{array}{c}-0.013^{* * *} \\
(0.002)\end{array}$ & $\begin{array}{c}-0.010^{* * *} \\
(0.000)\end{array}$ & $\begin{array}{c}-0.011 \text { *** } \\
(0.001)\end{array}$ & $\begin{array}{c}-0.010^{* * *} \\
(0.001)\end{array}$ \\
\hline Total family assets & $\begin{array}{c}-0.001^{* * *} \\
(0.000)\end{array}$ & $\begin{array}{c}-0.001^{* * *} \\
(0.000)\end{array}$ & $\begin{array}{c}-0.001^{* * *} \\
(0.000)\end{array}$ & $\begin{array}{c}-0.001^{* * * *} \\
(0.000)\end{array}$ \\
\hline Endowment insurance participation & $\begin{array}{c}-0.900 * * * \\
(0.003)\end{array}$ & $\begin{array}{c}-0.925^{* * *} \\
(0.003)\end{array}$ & $\begin{array}{c}-0.949^{* * * *} \\
(0.001)\end{array}$ & $\begin{array}{c}-0.964^{* * *} \\
(0.002)\end{array}$ \\
\hline Endowment insurance balance & $\begin{array}{c}0.000 \\
(0.000)\end{array}$ & $\begin{array}{c}0.000^{* * *} \\
(0.000)\end{array}$ & $\begin{array}{c}0.000 * * * \\
(0.000)\end{array}$ & $\begin{array}{c}0.000 * * * \\
(0.000)\end{array}$ \\
\hline Medical insurance participation & $\begin{array}{c}-0.192 * * * \\
(0.004)\end{array}$ & $\begin{array}{c}-0.070^{* * *} \\
(0.003)\end{array}$ & $\begin{array}{c}-0.125^{* *} \\
(0.002)\end{array}$ & $\begin{array}{c}-0.242^{* * *} \\
(0.016)\end{array}$ \\
\hline Medical insurance balance & $\begin{array}{c}-0.003^{* * *} \\
(0.000)\end{array}$ & $\begin{array}{c}-0.007^{* * * *} \\
(0.001)\end{array}$ & $\begin{array}{c}-0.002 * * * \\
(0.000)\end{array}$ & $\begin{array}{c}-0.001 \text { * } \\
(0.000)\end{array}$ \\
\hline Constant & $\begin{array}{c}1.955^{* * *} \\
(0.015)\end{array}$ & $\begin{array}{c}1.273^{* * *} \\
(0.008)\end{array}$ & $\begin{array}{c}1.463^{* * *} \\
(0.007)\end{array}$ & $\begin{array}{c}1.968^{* * *} \\
(0.045)\end{array}$ \\
\hline
\end{tabular}

Notes: ${ }^{* * *},{ }^{* *},{ }^{*}$ showing significance at $1 \%, 5 \%$, and $10 \%$ probability levels, respectively; standard errors are in parenthesis.

\section{Conclusions and Implications}

This paper measures farm household vulnerability to poverty of Chinese farm households by using three-stage generalized feasible generalized least squares (FGLS) and researches the effect of different credit channels on farm household vulnerability to poverty by using quantile regression. This paper comes to the following conclusions through theoretical analysis and empirical verification:

Firstly, raising the poverty line can make a farm household's vulnerability to poverty increase. With the increase of the vulnerability line, the rate of farm household vulnerability to poverty decreases. According to the horizontal comparison of the poverty level, the structural poverty proportion in the western region is relatively large, while the risk poverty proportion in the eastern region is comparatively large.

Secondly, from theory analysis, we get that different credit channels have different effects on poverty eradication; private credit can only help farm households get temporary help in life. However, it has little effect on their development of production and long-term poverty alleviation. From the empirical test, we also get that folk loans have an insignificant effect on reducing farm household vulnerability to poverty.

Thirdly, bank credit can help farm households improve their productivity, reduce persistent poverty, and reduce vulnerability to poverty. 
Lastly, we get that farm households with higher vulnerability to poverty are more likely to reduce their vulnerability by bank credit.

The corresponding policy implications are as follows. Different credit channels in rural credit markets have developed in tandem, which can alleviate credit constraints faced by farm households, help farm households increase production, and reduce poverty. In the rural formal financial market, all kinds of banks, insurance companies, new financial institutions, and so on, should be given full play. In addition, they are encouraged to go deep into the countryside by supplying financial services and infrastructure construction. Consequently, improving rural financial service coverage and permeability, and enriching and innovating financial products and processes are accomplished. More credit in the era of big data by using Internet technology is realized, which achieves cost reduction and improves the repayment rates. Farm household financial literacy is improved, and the role of financial resources in promoting the development of agriculture, rural areas, and farmers is given full play. The rural financial service environment is improved by strengthening the use of the Internet, smartphones, big data, and other modern technology, which expands the depth of the financial service network. Rural folk loans have necessity and rationality because of its function of temporarily relieving risk. In this regard, we can actively build a service platform for informal borrowing and lending behavior in rural areas, creating a fair, just, and legal environment for informal borrowing and lending. We can also guide and promote the standardized development of informal borrowing and the lending market, and give full play to and enhance the poverty alleviation effect of informal borrowing and lending.

Despite the contributions of this study, it is not free from limitations and some further questions need to be studied. First, a phenomenon has been observed in the paper, but the reasons have not been explained. Therefore, we could research the reasons next, namely, the mechanism of credit channels on vulnerability to poverty alleviation. Second, after the year 2020, there is no absolute poverty under the current standard in China, and, therefore, relative poverty will become an important issue. Therefore, how credit channels affect relative poverty will become another subject with important practical significance. Lastly, the two aspects, as discussed above, are from the financial demand side; we can also research how to supply financial products from the supply side, which can reduce risk, and increase farmer income and promote economic development further in rural areas.

Author Contributions: Investigation, H.S. and X.L.; Methodology, H.S. and X.L.; Writing—original draft, H.S.; Writing-review and editing, H.S., X.L., and W.L. The authors contributed significantly to the completion of this manuscript, conceiving and designing the research, writing and improving the paper. All authors have read and agreed to the published version of the manuscript.

Funding: The research was partially supported by the Construction Project of Domestic First-Class Discipline Economics and Management in Agriculture and Forestry of Guizhou University under Grant No. GNYL [2017]002, the Major Project to Study and Develop Marxist Theory under Grant No. 2019MZD006, the Guizhou University Social Sience Project in 2020 under Grant No. GDZX2020010, and the Wuhan Textile University Technology Innovation Plan Funds "Research on Long-term Poverty Alleviation Mechanism Stimulating the Endogenous Motivation of the Poor People".

Acknowledgments: The authors thank the editor and reviewers for their insightful comments. The authors thank the Southwestern University of Finance and Economics for supplying the data.

Conflicts of Interest: The authors declare no conflict of interest.

\section{References}

1. Zhang, C.; Xu, Q.; Zhou, X.; Zhang, X.; Xie, Y. Are poverty rates underestimated in China? New evidence from four recent surveys. China Econ. Rev. 2014, 31, 410-425. [CrossRef]

2. Chen, S.; Ravallion, M. The developing world is poorer than we thought, but no less successful in the fight against poverty. Q. J. Econ. 2010, 125, 1577-1625. [CrossRef]

3. Bourguignon, F.; Chakravarty, S.R. The measurement of multidimensional poverty. In Poverty, Social Exclusion and Stochastic Dominance; Springer: Singapore, 2019; pp. 83-107. 
4. Chaudhuri, S.; Jalan, J.; Suryahadi, A. Assessing Household Vulnerability to Poverty from Cross-Sectional Data: A Methodology and Estimates from Indonesia; Discussion Paper No. 0102-52; Columbia University: New York, NY, USA, 2002.

5. Skoufias, E.; Quisumbing, A.R. Consumption insurance and vulnerability to poverty: A synthesis of the evidence from Bangladesh, Ethiopia, Mali, Mexico and Russia. Eur. J. Dev. Res. 2005, 17, 24-58. [CrossRef]

6. Seipel, M.M.O. Global poverty: No longer an untouchable problem. Int. Soc. Work 2003, 46, $191-207$. [CrossRef]

7. Gulli, H. Microfinance and Poverty: Questioning the Conventional Wisdom; Inter-American Development Bank Sustainable Development Dept. Micro Enterprise Unit: Washington, DC, USA, 1998.

8. Bakhtiari, S. Microfinance and poverty reduction: Some international evidence. Int. Bus. Econ. Res. J. 2006, 5, 65. [CrossRef]

9. Urrea, M.A.; Maldonado, J.H. Vulnerability and risk management: The importance of financial inclusion for beneficiaries of conditional transfers in Colombia. Can. J. Dev. Stud./Rev. Can. D'études Du Dév. 2011, 32, 381-398. [CrossRef]

10. Choudhury, M.A. Tawhidi Epistemology and Its Applications: Economics, Finance, Science, and Society; Cambridge Scholars Publishing: Cambridge, UK, 2014.

11. Maldonado, J.H.; González-Vega, C. Impact of microfinance on schooling: Evidence from poor rural households in Bolivia. World Dev. 2008, 36, 2440-2455. [CrossRef]

12. Gutierrez, J.A.; Martinez, V.; Tse, Y. Where does return and volatility come from? The case of Asian ETFs. Int. Rev. Econ. Financ. 2009, 18, 671-679. [CrossRef]

13. Van Rooyen, C.; Stewart, R.; De Wet, T. The impact of microfinance in sub-Saharan Africa: A systematic review of the evidence. World Dev. 2012, 40, 2249-2262. [CrossRef]

14. Kinnan, C.; Townsend, R. Kinship and financial networks, formal financial access, and risk reduction. Am. Econ. Rev. 2012, 102, 289-293. [CrossRef]

15. Ambrus, A.; Mobius, M.; Szeidl, A. Consumption risk-sharing in social networks. Am. Econ. Rev. 2014, 104, 149-182. [CrossRef]

16. Geda, A.; Shimeless, A. Openness, Inequality and Poverty in Africa; Working Papers 25; United Nations, Department of Economics and Social Affairs: New York, NY, USA, 2006.

17. Liverpool, L.S.O.; Winter-Nelson, A. Poverty status and the impact of formal credit on technology use and wellbeing among Ethiopian smallholders. World Dev. 2010, 38, 541-554. [CrossRef]

18. Barr, N. Labor Markets and Social Policy in Central and Eastern Europe: The Accession and Beyond; The World Bank Publications: Washington, DC, USA, 2005.

19. Mahjabeen, R. Microfinancing in Bangladesh: Impact on households, consumption and welfare. J. Policy Model. 2008, 30, 1083-1092. [CrossRef]

20. Morduch, J.; Haley, B. Analysis of the Effects of Microfinance on Poverty Reduction; NYU Wagner Working Paper; NYU Wagner: New York, NY, USA, 2002; Volume 1014.

21. Giné, X.; Karlan, D.; Zinman, J. Put your money where your butt is: A commitment contract for smoking cessation. Am. Econ. J. Appl. Econ. 2010, 2, 213-235. [CrossRef]

22. Islam, A.; Maitra, P. Health shocks and consumption smoothing in rural households: Does microcredit have a role to play? J. Dev. Econ. 2012, 97, 232-243. [CrossRef]

23. Field, E.; Jayachandran, S.; Pande, R. Do traditional institutions constrain female entrepreneurship? A field experiment on business training in India. Am. Econ. Rev. 2010, 100, 125-129. [CrossRef]

24. Rahman, N.; Iverson, S. Big data business intelligence in bank risk analysis. Int. J. Bus. Intell. Res. 2015, 6, 55-77. [CrossRef]

25. Remenyi, J.; Quinones, B. Microfinance and Poverty Alleviation; Pinter: London, UK, 2000.

26. Van Kerkhove, M.D.; Vandemaele, K.A.H.; Shinde, V.; Jaramillo-Gutierrez, G.; Koukounari, A.; Donnelly, C.A.; Carlino, L.O.; Owen, R.; Paterson, B.; Pelletier, L.; et al. Risk factors for severe outcomes following 2009 influenza A (H1N1) infection: A global pooled analysis. PLoS Med. 2011, 8, e1001053. [CrossRef]

27. Copestake, J.; Dawson, P.; Fanning, J.P.; McKay, A.; Wright-Revolledo, K. Monitoring the diversity of the poverty outreach and impact of microfinance: A comparison of methods using data from Peru. Dev. Policy Rev. 2005, 23, 703-723. [CrossRef] 
28. Burgess, R.; Pande, R. Do rural banks matter? Evidence from the Indian social banking experiment. Am. Econ. Rev. 2005, 95, 780-795. [CrossRef]

29. Martin, R. Geography and public policy: The case of the missing agenda. Prog. Hum. Geogr. 2001, 25, 189-210. [CrossRef]

30. Chen, S.; Ravallion, M. Absolute Poverty Measures for the Developing World, 1981-2004. Proc. Natl. Acad. Sci. USA 2007, 104, 16757-16762. [CrossRef] [PubMed]

31. Beck, T.; Demirgüç-Kunt, A.; Maksimovic, V. The influence of financial and legal institutions on firm size. J. Bank. Financ. 2006, 30, 2995-3015. [CrossRef]

32. Spiller, P.T. Transaction cost regulation. J. Econ. Behav. Organ. 2013, 89, 232-242. [CrossRef]

33. Li, L. Financial inclusion and poverty: The role of relative income. China Econ. Rev. 2018, 52, $165-191$. [CrossRef]

34. Jalilian, H.; Kirkpatrick, C. Financial development and poverty reduction in developing countries. Int. J. Financ. Econ. 2002, 7, 97-108. [CrossRef]

35. Jalilian, H.; Kirkpatrick, C. Does financial development contribute to poverty reduction? J. Dev. Stud. 2005, 41, 636-656. [CrossRef]

36. Dollar, D.; Kraay, A. Trade, Growth, and Poverty. Econ. J. 2004, 114, F22-F49. [CrossRef]

37. Huang, X.; Dijst, M.; Van Weesep, J.; Zou, N. Residential mobility in China: Home ownership among rural-urban migrants after reform of the hukou registration system. J. Hous. Built Environ. 2014, 29, 615-636. [CrossRef]

38. Beck, T.; Demirgüç-Kunt, A.; Levine, R. Finance, Inequality, and Poverty: Cross-Country Evidence; World Bank Policy Research Working Paper No. 3338; The World Bank: Washington, DC, USA, 2004.

39. Kpodar, K.; Jeanneney, S.G. Financial Development and poverty Reduction: Can there be a benefit without a cost? IMF Work. Pap. 2008, 8, 62.

40. Akhtar, M.I.; Hamid, M.; Minai, F.; Wali, A.R.; Anwar-ul-Haq; Aman-Ullah, M.; Ahsan, K. Safety profile of fast-track extubation in pediatric congenital heart disease surgery patients in a tertiary care hospital of a developing country: An observational prospective study. J. Anaesthesiol. Clin. Pharmacol. 2014, 30, 355. [CrossRef] [PubMed]

41. Greenwood, J.; Jovanovic, B. Financial development, growth, and the distribution of income. J. Political Econ. 1990, 98, 1076-1107. [CrossRef]

42. Aghion, P.; Bolton, P. A theory of trickle-down growth and development. Rev. Econ. Stud. 1997, 64, 151-172. [CrossRef]

43. Lloyd-Ellis, H.; Bernhardt, D. Enterprise, inequality and economic development. Rev. Econ. Stud. 2000, 67, 147-168. [CrossRef]

44. Trew, A. Finance and growth: A critical survey. Econ. Rec. 2006, 82, 481-490. [CrossRef]

45. Kaboski, J.P.; Townsend, R.M. The impact of credit on village economies. Am. Econ. J. Appl. Econ. 2012, 4, 98-133. [CrossRef]

46. Chakraborty, S.; Ray, T. The development and structure of financial systems. J. Econ. Dyn. Control 2007, 31, 2920-2956. [CrossRef]

47. Galor, O.; Zeira, J. Income distribution and macroeconomics. Rev. Econ. Stud. 1993, 60, 35-52. [CrossRef]

48. Ravallion, M. Growth, inequality and poverty: Looking beyond averages. World Dev. 2001, 29, $1803-1815$. [CrossRef]

49. Karlan, D.; Zinman, J. Observing unobservables: Identifying information asymmetries with a consumer credit field experiment. Econometrica 2009, 77, 1993-2008.

50. Fafchamps, M.; Gubert, F. The formation of risk sharing networks. J. Dev. Econ. 2007, 83, 326-350. [CrossRef]

51. Munshi, K.; Rosenzweig, M. Networks and misallocation: Insurance, migration, and the rural-urban wage gap. Am. Econ. Rev. 2016, 106, 46-98. [CrossRef]

52. Cai, S.; Lin, X.; Xu, D.; Fu, X. Judging online peer-to-peer lending behavior: A comparison of first-time and repeated borrowing requests. Inf. Manag. 2016, 53, 857-867. [CrossRef]

53. Imai, K.S.; Arun, T.; Annim, S.K. Microfinance and household poverty reduction: New evidence from India. World Dev. 2010, 38, 1760-1774. [CrossRef] 
54. Sun, H.; Hartarska, V.; Zhang, L.; Nadolnyak, D. The influence of social capital on farm household's borrowing behavior in Rural China. Sustainability 2018, 10, 4361. [CrossRef]

55. Amemiya, T. The maximum likelihood and the nonlinear three-stage least squares estimator in the general nonlinear simultaneous equation model. Econom. J. Econom. Soc. 1977, 955-968. [CrossRef]

(C) 2020 by the authors. Licensee MDPI, Basel, Switzerland. This article is an open access article distributed under the terms and conditions of the Creative Commons Attribution (CC BY) license (http://creativecommons.org/licenses/by/4.0/). 